\title{
Consumption of thermally-oxidized sunflower oil by chicks reduces $\alpha$-tocopherol status and increases susceptibility of tissues to lipid oxidation
}

\author{
BY P. J. A. SHEEHY, P. A. MORRISSEY* AND A. FLYNN \\ Department of Nutrition, University College, Cork, Republic of Ireland
}

(Received 17 August 1992-Revised 8 February 1993-Accepted 18 March 1993)

\begin{abstract}
The effect of heated sunflower oil consumption on $\alpha$-tocopherol status, fatty acid composition and oxidative stability of chicken tissues was investigated. Chicks were fed on diets containing $(\mathrm{g} / \mathrm{kg})$ : fresh sunflower oil (FSO) 40, heated sunflower oil (HSO) 40 or heated sunflower oil (40) supplemented with $\alpha$-tocopheryl acetate (HSE) to a similar $\alpha$-tocopherol concentration as the FSO diet. Concentrations of $\alpha$-tocopherol in tissues of chicks fed on HSO and HSE were significantly lower than those of chicks fed on FSO. Significant correlations were observed between plasma $\alpha$-tocopherol concentration and the $\alpha$-tocopherol concentrations of other tissues $(r \geqslant 0.67, P<0.005)$ and between log plasma $\alpha$-tocopherol and plasma thiobarbituric acid-reacting substances (TBARS) concentrations $(r-0.851, P<0.001)$. The concentrations of TBARS in tissues of chicks fed on the various diets were generally very similar before stimulation of peroxidation with $\mathrm{Fe}$-ascorbate. Susceptibility of tissues to $\mathrm{Fe}$-ascorbate-induced lipid peroxidation was increased by feeding HSO. Supplementation with $\alpha$-tocopheryl acetate reduced susceptibility to lipid oxidation to varying degrees, depending on the tissue. The results suggest that chronic ingestion of oxidized lipids may compromise free-radical-scavenging activity in vivo by depleting $\alpha$-tocopherol in the gastrointestinal tract, or possibly in plasma and other tissues.
\end{abstract}

Heated oils: $\alpha$-Tocopherol: Lipid peroxidation: Chick

The safety of thermally-abused fats and oils for human and animal consumption has been the subject of research over many years. Although feeding oxidized lipids to different species can result in a wide variety of symptoms including reduced appetite, growth depression, diarrhoea, histological changes in tissues and even death (Izaki et al. 1984), the general consensus has been that consumption of thermally-abused fats at realistic levels is not harmful since the dietary intake of lipid oxidation products is likely to be low (Artman, 1969). In recent years this suggestion has been criticized on the basis that in many earlier studies the pathological end-points assessed were crude, and fatty acid oxidation products and cholesterol oxides have been implicated in mutagenesis and carcinogenesis, and in the aetiology of coronary heart disease (Addis \& Warner, 1991). There is considerable uncertainty over the degree to which lipid hydroperoxides and other oxidation products such as aldehydes, ketones, polymers and epoxides are absorbed from the intestine. Glavind et al. (1971) failed to observe peroxides in the lymphatic system of rats fed on oxidized lipids. However, Kanazawa et al. (1985) showed that some secondary oxidation products (but not hydroperoxides) are absorbed by rats and are taken up by the liver. Increased urinary excretion of malondialdehyde by rats following an oral dose of the enolic sodium salt was taken as indirect evidence of malondialdehyde absorption (Draper et al. 1984). Naruszewicz et al. (1987) observed a marked increase in plasma thiobarbituric acidreacting substances (TBARS) in human subjects after the ingestion of thermally-oxidized

\footnotetext{
* For reprints.
} 
soya-bean oil, while elevations in plasma TBARS after ingestion of fresh oil were minimal. These findings suggest that many lipid oxidation products may be absorbed by humans and animals. The fate of lipid oxidation products once formed in plasma or once they have been taken up by plasma is mainly unexplored (Frei et al. 1988). For these reasons, there is a need for further research into the biological effects of consumption of foods containing high levels of lipid oxidation products.

Fat blends for animal feeding may be based on waste fats from frying operations, or on byproducts such as distillation residues from edible-oil refining (Wiseman, 1986). In the broiler feed industry oxidation of feed ingredients can be costly to growers (Calabotta \& Shermer, 1985). A low level of feed oxidation causes growth depression in broilers (Calabotta \& Shermer, 1985; Lin et al. 1989), while feeding severely-oxidized vegetable oils containing high levels of linoleic acid to broilers may cause nutritional encephalopathy (NE) (Budowski et al. 1979, 1980). $\alpha$-Tocopherol is an important chain-breaking antioxidant in vivo (Burton et al. 1982, 1983, 1985 a; Ingold et al. 1987 b) and in meats after slaughter (Marusich, 1980). Although it is generally accepted that $\alpha$-tocopherol requirements of poultry are increased by consumption of thermally-oxidized lipids, there is little quantitative information on the effects of feeding such lipids on concentrations of $\alpha$-tocopherol in tissues, and on the fatty acid composition and oxidative stability of tissues. Lin et al. (1989) detected lower $\alpha$-tocopherol concentrations in dark and white muscle of broilers fed on standard all-mash diets supplemented with $55 \mathrm{~g}$ thermally-oxidized sunflower oil $/ \mathrm{kg}$ compared with those fed on diets supplemented with $55 \mathrm{~g}$ fresh oil $/ \mathrm{kg}$. However, the $\alpha$-tocopherol content of the oxidized-oil diet was considerably lower than that of the fresh-oil diet due to destruction of $\alpha$-tocopherol in sunflower oil by heating, making the evaluation of that study difficult. The purpose of the present study was to investigate the effects of feeding diets containing fresh or heated sunflower oil, with or without $\alpha$-tocopherol, on $\alpha$-tocopherol concentrations and fatty acid composition of chick tissues, as well as on the stability of these tissues against $\mathrm{Fe}$-ascorbate-induced lipid oxidation.

\section{MATERIALS AND METHODS}

\section{Chemicals}

All chemicals used were Analar grade obtained from British Drug House, Poole, Dorset, Sigma Chemical Co. Ltd., Poole, Dorset, and Rathburn Chemical Co. Ltd., Walkerburn, Peeblesshire. DL- $\alpha$-tocopheryl acetate (Rovimix E) used in diets was purchased from Roche Products Ltd., Welwyn Garden City, Herts.

\section{Animals and diets}

Thirty-six 1-d-old female ISA Brown chicks were obtained from a commercial hatchery and housed in an environmentally controlled room. The temperature of the room was $32^{\circ}$ during the first week, $28^{\circ}$ during week 2 and $26^{\circ}$ thereafter. A 12 h normal light-low light cycle was employed.

Chicks were randomly assigned to three groups and fed on glucose-soya-bean-based diets (Table 1), containing (g/kg): fresh sunflower oil (FSO) 40, heated sunflower oil (HSO) 40 or heated sunflower oil (40) supplemented with DL- $\alpha$-tocopheryl acetate (HSE) to a similar $\alpha$-tocopherol concentration as the fresh oil diet. Batches of sunflower oil were heated for $11 \mathrm{~h}$ at $120^{\circ}$. Air was constantly bubbled into the oil during heating. After determining the $\alpha$-tocopherol concentration in both fresh and heated oil, the $\alpha$-tocopherol level of the HSE diet was adjusted to that of the FSO diet. Butylated hydroxytoluene was added to the diets (via the oil) to a final dietary concentration of $0.05 \mathrm{~g} / \mathrm{kg}$, a level which protects linoleic acid and $\alpha$-tocopherol for over 1 week at room temperature (Budowski et al. 1979). Diets were prepared weekly and stored at $4^{\circ}$ during the experiment. As a check 
Table 1. Composition of diets fed to chicks $(\mathrm{g} / \mathrm{kg})^{*}$

\begin{tabular}{lcc}
\hline & $40 \cdot 0$ \\
& Sunflower oil $\dagger$ & $520 \cdot 0$ \\
& Soya-bean meal & $383 \cdot 6$ \\
Glucose monohydrate & $10 \cdot 0$ \\
Cellulose & $1 \cdot 40$ \\
DL-Methionine & $40 \cdot 0$ \\
Mineral mix & $5 \cdot 00$ \\
& Vitamin mix & $0 \cdot 05$ \\
\hline
\end{tabular}

* Batches of diet were prepared weekly and stored at $4^{\circ}$.

$\dagger$ Fresh sunflower oil (FSO), heated sunflower oil $\left(120^{\circ} \times 11 \mathrm{~h}\right.$ with constant agitation; HSO), or heated sunflower oil supplemented with $\alpha$-tocopheryl acetate (HSE).

$\ddagger$ Supplying (mg/kg feed): $\mathrm{CaHPO}_{4} 28 \mathrm{~g}, \mathrm{CaCO}_{3} 7 \mathrm{~g}, \mathrm{NaCl} 3 \cdot 5 \mathrm{~g}, \mathrm{MnSO}_{4} \cdot 4 \mathrm{H}_{2} \mathrm{O} 488, \mathrm{ZnCO}_{3} 145$, Ferric citrate $165, \mathrm{CuSO}_{4} .4 \mathrm{H}_{2} \mathrm{O} 11 \cdot 8, \mathrm{Kl} 2 \cdot 35 ; \mathrm{CoSO}_{4} .8 \mathrm{H}_{2} \mathrm{O} 1 \cdot 45$.

\$ Supplying (mg/kg feed): retinol $3000 \mathrm{IU}$, cholecalciferol $200 \mathrm{IU}$, menadione sodium bisulphite 1 , thiamine $3 \cdot 6$, riboflavin $7 \cdot 2$, calcium pantothenate 20 , niacin 55 , pyridoxine 6 , biotin $0 \cdot 2$, folic acid $2 \cdot 4$, cyanocobalamin $0 \cdot 02$, choline chloride $1.3 \mathrm{~g}$.

These amounts were premixed with $3.6 \mathrm{~g}$ glucose monohydrate.

on the accuracy of formulation, pooled samples of diet were stored at $-20^{\circ}$ and the $\alpha$ tocopherol concentrations measured in triplicate at the end of the experiment. The diets were found to contain (mg $\alpha$-tocopherol $/ \mathrm{kg}$ ): FSO $30 \cdot 0$ (SE 3.9), HSE $25 \cdot 1$ (SE 1.1), HSO 1.3 (SE $0 \cdot 4)$. Peroxide values of typical batches of fresh and heated oils (measured in triplicate) were (mg peroxide-O/kg): 7.73 (SE 1.79) and 66.3 (SE 5.90), while the I values were 97.3 (SE 2.85) and 89.0 (SE 5.11) respectively. A small but significant decrease in the concentration of linoleic acid (18:2n-6) was observed in sunflower oil after heating (Table 2).

Groups of chicks were housed in raised wire cages $(1.2 \times 1.0 \times 0.8 \mathrm{~m})$. Feed and water were provided ad lib. Body weights were determined twice weekly. After $32 \mathrm{~d}$ the chicks were fasted overnight, and killed by cervical dislocation. Blood was collected and plasma prepared by centrifugation at $1000 \mathrm{~g}$ for $25 \mathrm{~min}$. Tissues were frozen in liquid $\mathrm{N}_{2}$ and stored at $-20^{\circ}$ until required.

\section{Analytical methods}

$\alpha$-Tocopherol was extracted from unsaponified plasma with hexane by the method of Shearer (1986). The hexane was evaporated with $\mathrm{N}_{2}$ at $37^{\circ}$ and the residue re-dissolved in $100 \mu 1$ absolute alcohol. Tissues and oils were saponified by the method of Buttriss \& Diplock (1984) before extraction of $\alpha$-tocopherol. Tissues were homogenized in ice-cold $\mathrm{KCl}(11.5 \mathrm{~g} / \mathrm{l})$. Homogenate $(1 \mathrm{ml})$ was added to $2 \mathrm{ml}$ pyrogallol $(10 \mathrm{~g} / \mathrm{l})$ in absolute alcohol, followed by $0.3 \mathrm{ml}$ saturated $\mathrm{KOH}$. The mixture was heated at $70^{\circ}$ for $30 \mathrm{~min}$, extracted once with $5 \mathrm{ml}$ hexane-water $(4: 1, \mathrm{v} / \mathrm{v})$, twice with hexane $(2 \mathrm{ml})$, and centrifuged to separate the aqueous and organic layers. The hexane was evaporated under $\mathrm{N}_{2}$ and the residue re-dissolved in $100 \mu \mathrm{l}$ absolute alcohol. A similar procedure was performed for oils, except that samples of $20 \mathrm{mg}$ oil were used. The $\alpha$-tocopherol content of diets was determined after saponification by the method of Brubacher et al. (1985). Methanolic ascorbic acid $(50 \mathrm{ml})$ and $\mathrm{KOH}(500 \mathrm{~g} / 1 ; 10 \mathrm{ml})$ were added to finely ground samples of diet $(10 \mathrm{~g})$. The mixture was simmered on a steam bath under $\mathrm{N}_{2}$ for $20 \mathrm{~min}$, allowed to cool, and extracted three times with diethyl ether. The diethyl ether layer was collected using a separating funnel, removed by rotary evaporation, and the residue redissolved in absolute alcohol. $\alpha$-Tocopherol was measured by reverse-phase HPLC using a Licrosorb RP18 $(5 \mu \mathrm{m})$ column, a mobile phase of methanol-water $(97: 3, \mathrm{v} / \mathrm{v})$ at $2.5 \mathrm{ml} / \mathrm{min}$, and detection at $292 \mathrm{~nm}$, as previously described (Sheehy et al. 1991). Recovery of $\alpha$-tocopherol from plasma was determined by the addition of an internal standard, $\alpha$ - 
Table 2. Fatty acid composition ( $\mathrm{g} / 100 \mathrm{~g}$ total fatty acids) of diets containing fresh sunflower oil (FSO), heated, $\alpha$-tocopheryl acetate-supplemented sunflower oil (HSE) or heated sunflower oil (HSO) fed to chicks*

(Mean values with their standard errors)

\begin{tabular}{|c|c|c|c|c|c|c|}
\hline \multirow[b]{2}{*}{ Fatty acid } & \multicolumn{2}{|c|}{$\mathrm{FSO}$} & \multicolumn{2}{|c|}{ HSE } & \multicolumn{2}{|c|}{$\mathrm{HSO}$} \\
\hline & Mean & $\mathrm{SE}$ & Mean & $\mathrm{SE}$ & Mean & $\mathrm{SE}$ \\
\hline $14: 0$ & $2 \cdot 27$ & 0.65 & 0.80 & 0.08 & 0.91 & 0.01 \\
\hline $16: 0$ & $8 \cdot 69$ & 0.06 & $9 \cdot 20$ & 0.08 & $9 \cdot 45$ & 0.14 \\
\hline $18: 0$ & $3 \cdot 52$ & 0.04 & $3 \cdot 73$ & 0.09 & 3.86 & 0.02 \\
\hline $18: 1$ & $26 \cdot 4$ & $0 \cdot 34$ & $28 \cdot 1$ & 0.06 & $27 \cdot 6$ & 0.09 \\
\hline $18: 2$ & $58 \cdot 7^{\mathrm{a}}$ & $0 \cdot 30$ & $57 \cdot 6^{6}$ & 0.14 & $57 \cdot 1^{c}$ & 0.07 \\
\hline $18: 3$ & $0 \cdot 39$ & 0.01 & 0.38 & 0.01 & 0.37 & 0.02 \\
\hline Others & & $0 \cdot 00$ & $0 \cdot 17$ & $0 \cdot 10$ & 0.55 & 0.12 \\
\hline
\end{tabular}

a.b.c Means with unlike superscript letters were significantly different $(P<0.05)$.

* For details of dietary composition, see Table 1.

tocopheryl acetate, to each sample before extraction. Because of the need for saponification, mean recoveries of $\alpha$-tocopherol from diets, oils and tissues were estimated by spiking samples with graded amounts of $\alpha$-tocopherol before saponification. Recovery was calculated from the slope ratio of the regression lines for observed and expected $\alpha$ tocopherol concentration. Mean recoveries of $\alpha$-tocopherol were always greater than $90 \%$.

The concentrations of TBARS in plasma were determined by a spectrofluorometric method (Yagi, 1984). Tissue homogenates were assayed for TBARS before and after stimulation of lipid peroxidation with $\mathrm{Fe}$ ascorbate by a modification of the method of Kornbrust \& Mavis (1980). To a screw-capped glass tube was added $500 \mu \mathrm{l}$ Tris maleate buffer $(80 \mathrm{~mm}, \mathrm{pH} 7 \cdot 4) ; 200 \mu \mathrm{FeSO}_{4} .7 \mathrm{H}_{2} \mathrm{O}(5 \mathrm{~mm}) ; 200 \mu \mathrm{l}$ ascorbic acid solution $(2 \mathrm{~mm})$ and $100 \mu \mathrm{l}$ tissue homogenate $(100 \mathrm{mg} / \mathrm{ml})$. Solutions were incubated for various lengths of time in a shaking water-bath at $37^{\circ}$. Following incubation the reaction was terminated and the TBARS concentration determined by the method of Beuge \& Aust (1978). TBARS were expressed as nmol malondialdehyde $(\mathrm{MDA}) / \mathrm{mg}$ tissue protein using $\mathrm{E}_{\mathrm{MDA}}=$ $1.56 \times 10^{5} / \mathrm{M}$ per $\mathrm{cm}$. Protein was determined by the method of Lowry et al. (1951).

Neutral and polar lipids were extracted from $0.25-1.0 \mathrm{~g}$ tissue samples by the dry column method of Marmer \& Maxwell (1981). BHT $(0.05 \mathrm{~g} / \mathrm{l})$ was added to the extracting solvents. Following extraction the solvent was removed using a rotary evaporator and the lipids were re-dissolved in $5 \mathrm{ml}$ hexane. Neutral lipids were converted to their methyl esters with methanolic $\mathrm{BF}_{3}$ (Slover \& Lanza, 1979), while those of polar lipids were esterified using $2 \mathrm{M}$ $\mathrm{KOH}$ in methanol (Maxwell \& Marmer, 1983). Total lipids in diets were extracted by the method of Burton et al. $(1985 \mathrm{~b})$. To prepare fatty acid methyl esters, $1 \mathrm{ml}$ of the interesterification reagent (methanolic $\mathrm{BF}_{3}$-benzene-methanol, 25:20:55, by vol.) was added and the samples heated for $30 \mathrm{~min}$ at $100^{\circ}$. Following addition of $1 \mathrm{ml}$ water and $2 \mathrm{ml}$ hexane, samples were shaken for $2 \mathrm{~min}$, centrifuged and the hexane layer stored at $-20^{\circ}$. Fatty acid methyl esters were analysed by GLC, using a Shimadzu gas-liquid chromatograph equipped with a Silar $10-\mathrm{C}$ packed column. The oven temperature was held at $165^{\circ}$ for $2 \mathrm{~min}$, increased by $3^{\circ}$ per min to $225^{\circ}$, held for $2 \mathrm{~min}$, increased by $20^{\circ}$ per min to a final temperature of $235^{\circ}$ and held for $7 \mathrm{~min}$. Injector and detector temperatures were $300^{\circ}$. Fatty acid methyl esters were identified by comparison of retention times with those of authentic standards. 
Peroxide values of the fresh and heated oils were determined by the method of Lea (1946).

\section{Statistical analysis}

Statistical significance of the difference between means was determined by Student's $t$ test, while linear regression was used to assess the relationship between $a$-tocopherol and TBARS concentrations. All statistical procedures used routines available in the Minitab Statistical Package (Ryan et al. 1986).

\section{RESULTS}

The effect of feeding diets containing fresh or heated sunflower oils on body-weight gain of chicks is shown in Fig. 1. Although feeding HSO reduced weight gain, mean body weights of the three groups did not differ significantly until day 32. At this point, however, mean body weights of chicks fed on HSO were significantly lower than those of chicks fed on FSO $(-7.6 \%)$, or HSE $(-8.2 \%)$.

Table 3 shows the effect of feeding chicks on HSO, HSE or FSO on the $\alpha$-tocopherol concentrations of plasma and other tissues. High $\alpha$-tocopherol concentrations were found in heart, liver, lung and spleen while low concentrations were found in thigh muscle, pancreas, brain and breast muscle. With the exception of brain, concentrations of $\alpha$ tocopherol in tissues of chicks fed on FSO were significantly higher than those of chicks fed on HSE. In turn, the values for the latter group were significantly higher than those of the group fed on HSO. The concentrations of $\alpha$-tocopherol in tissues of the group fed on HSE, expressed as a percentage of those of the group fed on FSO, are also shown in Table 3. Tocopherol concentrations in tissues of chicks fed on HSE ranged from 29.6 to $86.1 \%$ of those of the FSO group, with the greatest depression in $\alpha$-tocopherol concentration being evident in liver, heart and plasma. The relationship between plasma $\alpha$-tocopherol concentration and the concentration of $\alpha$-tocopherol in tissues was investigated by linear regression (Table 3 ). A statistically significant direct correlation was observed between plasma $\alpha$-tocopherol concentration and the concentration of $\alpha$-tocopherol in other tissues, the correlation coefficients ranging from 0.67 (plasma $\alpha$-tocopherol $v$. pancreas $\alpha$-tocopherol) to 0.94 (plasma $\alpha$-tocopherol $v$. spleen $\alpha$-tocopherol).

Chicks fed on HSO had significantly higher TBARS concentrations in plasma compared with both HSE and FSO groups (Fig. 2). However, values for the HSE and FSO groups did not differ significantly with respect to each other. The relationship between $\alpha-$ tocopherol and lipid peroxide concentrations in plasma is shown in Fig. 3. A statistically significant negative correlation was observed between the log of plasma $\alpha$-tocopherol concentration and the concentration of TBARS in plasma.

Fig. 4 shows the effect of feeding HSO, HSE or FSO to chicks on TBARS concentrations in tissues, before and after stimulation of peroxidation with $\mathrm{Fe}$-ascorbate. Before stimulation TBARS concentrations in tissues from the various groups were generally very similar. Peroxidation was stimulated by incubating tissue homogenates with $\mathrm{Fe}$-ascorbate at $37^{\circ}$ for various lengths of time. With the exception of brain, tissues from chicks fed on HSO peroxidized more rapidly than those of the other two groups, while the rate of peroxidation of tissue homogenates from chicks fed on HSE was generally faster than those of the group fed on FSO.

The effect of feeding HSO, HSE or FSO on the fatty acid composition of chick tissues was also investigated. No significant differences in fatty acid composition of neutral or polar lipids of breast muscle and brain were observed between groups (values not shown). Slight changes were observed in the proportions of 18:0, 18:1, 20:5 and 22:0 in liver neutral lipids, and in the content of $18: 1$ in polar lipids of chicks fed on different diets. However, these changes were small and no definite trends were discernable (values not 


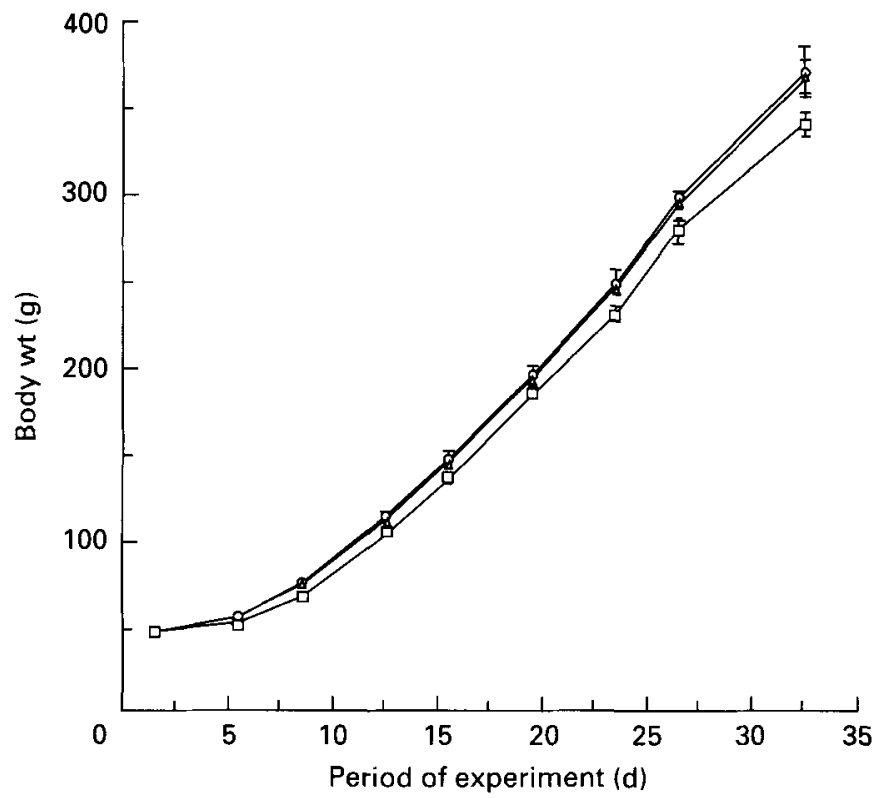

Fig. 1. Body weights of chicks fed on diets containing fresh sunflower oil (FSO; $\triangle$ ), heated sunflower oil (HSO; $\square$ ), or heated, $\alpha$-tocopheryl acetate-supplemented sunflower oil (HSE; $O$ ). For details of diets and procedures, see Tables 1 and 2 and pp. 54-55. Points are means with their standard errors represented by vertical bars. Mean value for HSO was significantly different from that for FSO and HSE: ${ }^{*} P<0.05$.

Table 3. Effect of feeding heated sunflower oil (HSO), heated, a-tocopheryl acetatesupplemented sunflower oil (HSE) or fresh sunflower oil (FSO) on a-tocopherol concentrations in chicken tissues*

(Mean values with their standard errors)

\begin{tabular}{|c|c|c|c|c|c|c|c|c|c|}
\hline \multirow[b]{4}{*}{ Tissue } & \multirow{2}{*}{\multicolumn{6}{|c|}{$\begin{array}{c}\alpha \text {-Tocopherol } \\
(\mu \mathrm{g} / \mathrm{ml} \text { plasma or } \mathrm{ng} / \mathrm{mg} \text { protein })\end{array}$}} & \multirow{4}{*}{$\begin{array}{c}\text { HSE : FSO } \\
(\%) \\
\text { Mean }\end{array}$} & \multicolumn{2}{|c|}{$\begin{array}{l}\text { Relationship between plasma and } \\
\text { tissue } \alpha \text {-tocopherol concentrations }\end{array}$} \\
\hline & & & & & & & & & Statistical \\
\hline & \multicolumn{2}{|c|}{ HSE } & \multicolumn{2}{|c|}{ HSE } & \multicolumn{2}{|c|}{ FSO } & & & significance of \\
\hline & Mean & $\mathrm{SE}$ & Mean & SE & Mean & SE & & $(r)$ & $(P<)$ \\
\hline Plasma & $0.83^{a}$ & 0.08 & $6 \cdot 65^{\mathrm{b}}$ & $1 \cdot 01$ & $16 \cdot 6^{\mathrm{e}}$ & $1 \cdot 40$ & $40 \cdot 1$ & - & - \\
\hline Liver & $3 \cdot 00^{\mathrm{a}}$ & 0.96 & $40 \cdot 0^{\mathrm{h}}$ & $2 \cdot 20$ & $135^{\mathrm{c}}$ & 25.9 & $29 \cdot 6$ & $0 \cdot 765$ & 0.001 \\
\hline Heart & $10 \cdot 5^{a}$ & 1.80 & $106^{\mathrm{b}}$ & 5.50 & $326^{\mathrm{c}}$ & $54 \cdot 1$ & $32 \cdot 5$ & 0.926 & $0 \cdot 001$ \\
\hline Thigh muscle & $6 \cdot 07^{a}$ & 0.79 & $33 \cdot 4^{b}$ & $4 \cdot 30$ & $58 \cdot 1^{\mathrm{c}}$ & $4 \cdot 30$ & $57 \cdot 5$ & 0.934 & 0.001 \\
\hline Breast muscle & $4.59^{a}$ & 0.44 & $19 \cdot 1^{\mathrm{b}}$ & $2 \cdot 12$ & $28 \cdot 8^{\mathrm{c}}$ & 1.80 & $66 \cdot 3$ & 0.921 & 0.001 \\
\hline Lung & $14 \cdot 0^{\mathrm{a}}$ & $6 \cdot 20$ & $64 \cdot 6^{\mathrm{b}}$ & $8 \cdot 80$ & $147^{\mathrm{c}}$ & $32 \cdot 2$ & $43 \cdot 9$ & 0.771 & 0.001 \\
\hline Pancreas & $3 \cdot 06^{\mathrm{a}}$ & 0.73 & $26 \cdot 1^{\mathrm{b}}$ & $4 \cdot 30$ & $40 \cdot 2^{c}$ & $3 \cdot 40$ & $64 \cdot 9$ & 0.671 & 0.005 \\
\hline Spleen & $4.53^{\mathrm{a}}$ & 0.65 & $61 \cdot 0^{\mathrm{b}}$ & $4 \cdot 11$ & $121^{\mathrm{c}}$ & $10 \cdot 3$ & $50 \cdot 4$ & 0.937 & 0.001 \\
\hline Brain & $15 \cdot 5^{a}$ & 1.51 & $27 \cdot 9^{\mathrm{b}}$ & 2.91 & $32 \cdot 4^{b}$ & $3 \cdot 30$ & $86 \cdot 1$ & 0.753 & 0.005 \\
\hline
\end{tabular}

a. b, c Mean values for $\alpha$-tocopherol concentrations in horizontal rows with unlike superscript letters were significantly different $(P<0 \cdot 05)$.

* For details of diets and procedures, see Tables 1 and 2 and pp. 54-57. 


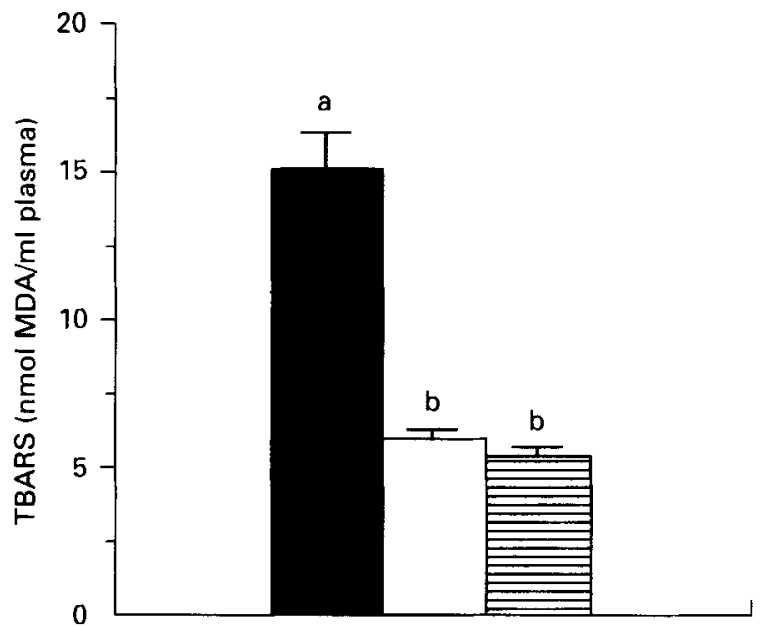

Fig. 2. Concentrations of thiobarbituric acid-reacting substances (TBARS) in plasma of chicks fed on heated sunflower oil (HSO; $\square$ ), heated, $\alpha$-tocopheryl acetate-supplemented sunflower oil (HSE; $\square$ ) or fresh sunflower oil (FSO; $\boxminus$ ). For details of diets and procedures, see Tables 1 and 2 and pp. 54-57. Points are means with their standard errors represented by vertical bars. ${ }^{a}, \mathrm{~b}$, Mean values with unlike superscript letters were significantly different $(P<0 \cdot 05)$. MDA, malondialdehyde.

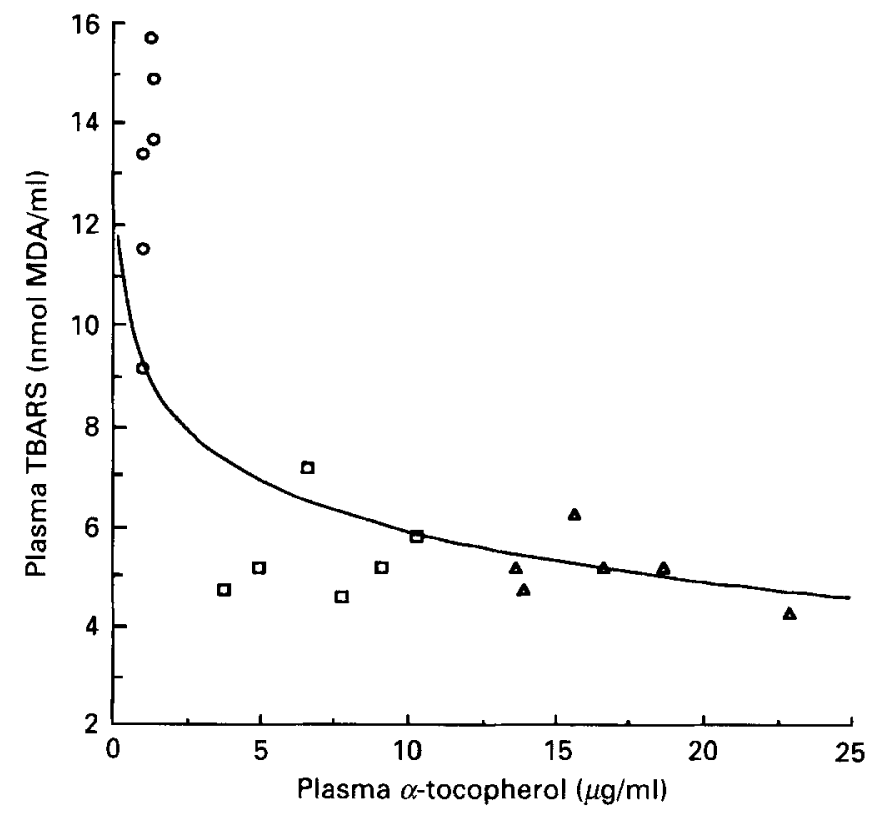

Fig. 3. Relationship between plasma concentrations of $\alpha$-tocopherol and thiobarbituric acid-reacting substances (TBARS) of chicks fed on diets containing heated sunflower oil (HSO; O), heated, $\alpha$-tocopheryl acetatesupplemented sunflower oil (HSO; $\square$ ), or fresh sunflower oil (FSO; $\triangle)(r=-0.851, P<0.001)$. For details of diets and procedures, see Tables 1 and 2 and pp. 54-57. MDA, malondialdehyde.

shown). Slight, but not significant, increases in the proportions of $18: 2,20: 4$ and total polyunsaturated fatty acids were observed in neutral lipids of heart and lung, as well as a decrease in monounsaturates (16:1 and 18:1) in heart neutral lipids, after feeding FSO (Tables 4 and 5). No significant differences were observed in the fatty acid composition of 

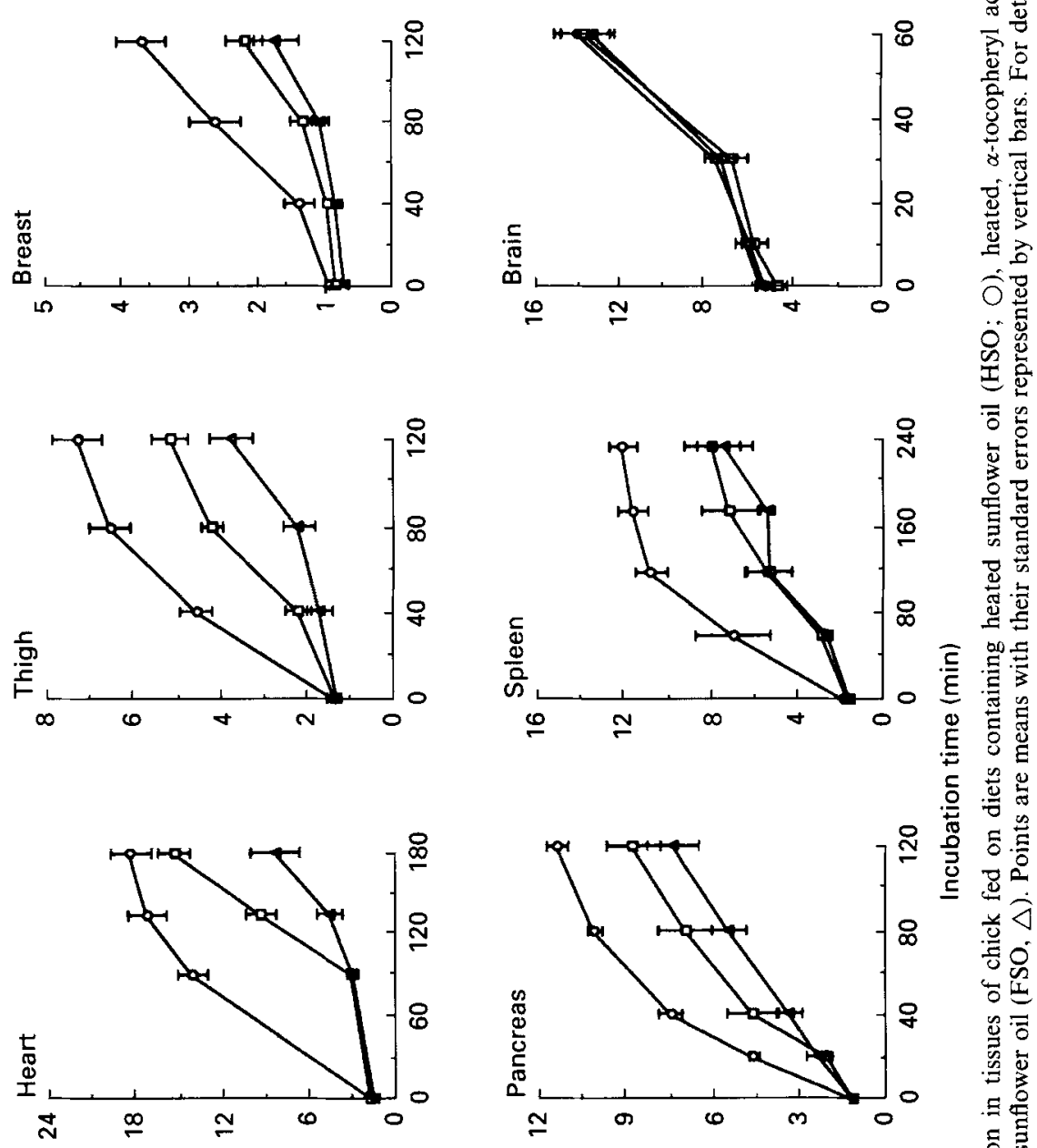

ᄃ

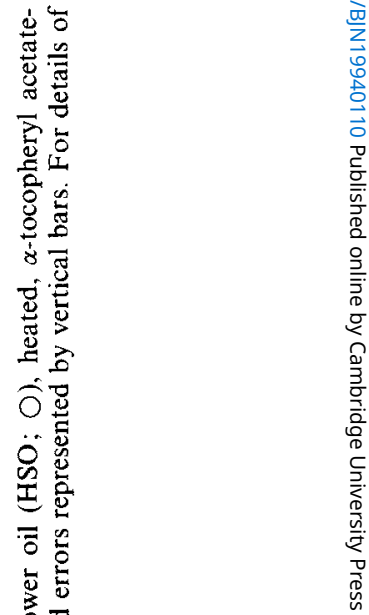
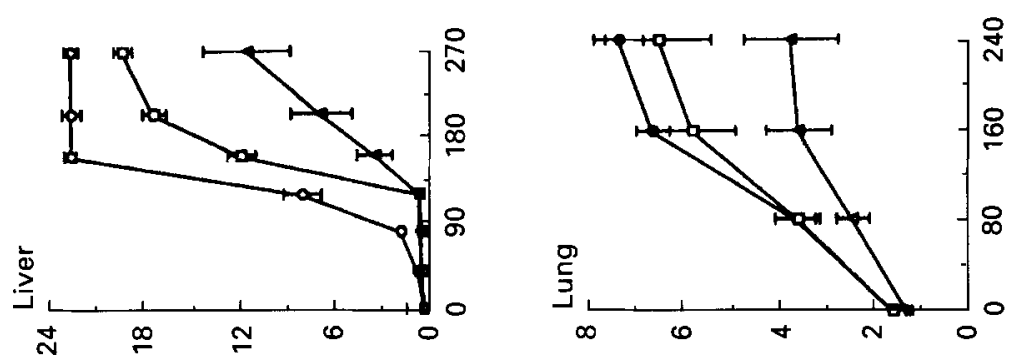

을

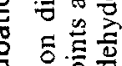
绨 능 응 政这 के $\overline{\frac{1}{2}}$ 密它 E

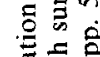

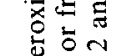
这管 궁 焉造 훙 ¿ 究言 (u!plosd $6 m / \forall a W$ loum) $S \forall \forall G \perp$

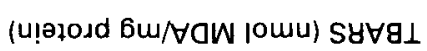


Table 4. Fatty acid composition ( $\mathrm{g} / 100 \mathrm{~g}$ total fatty acids) of neutral and polar lipid fractions of heart of chicks fed on diets containing heated sunflower oil (HSO), heated, a-tocopheryl acetate-supplemented sunflower oil (HSE) or fresh sunflower oil (FSO)*

(Mean values with their standard errors for six determinations)

\begin{tabular}{|c|c|c|c|c|c|c|c|c|c|c|c|c|}
\hline \multirow[b]{3}{*}{ Fatty acid } & \multicolumn{6}{|c|}{ Neutral lipids } & \multicolumn{6}{|c|}{ Polar lipids } \\
\hline & \multicolumn{2}{|c|}{$\mathrm{HSO}$} & \multicolumn{2}{|c|}{ HSE } & \multicolumn{2}{|c|}{ FSO } & \multicolumn{2}{|c|}{$\mathrm{HSO}$} & \multicolumn{2}{|c|}{ HSE } & \multicolumn{2}{|c|}{ FSO } \\
\hline & Mean & $\mathrm{SE}$ & Mean & $\mathrm{SE}$ & Mean & SE & Mean & $\mathrm{SE}$ & Mean & $\mathrm{SE}$ & Mean & $\mathrm{SE}$ \\
\hline $16 \cdot 0$ & $18 \cdot 7$ & 0.78 & $20 \cdot 2$ & $1 \cdot 29$ & $19 \cdot 5$ & $1 \cdot 39$ & $20 \cdot 5$ & $0 \cdot 27$ & $20 \cdot 7$ & 0.47 & $19 \cdot 7$ & 0.46 \\
\hline $16 \cdot 1$ & 2.59 & 0.43 & $3 \cdot 33$ & 0.13 & 1.96 & 0.32 & $1 \cdot 10$ & 0.42 & $1 \cdot 60$ & $0 \cdot 33$ & 1.45 & $0 \cdot 32$ \\
\hline 18.0 & $11 \cdot 3$ & 1.40 & $10 \cdot 5$ & 0.53 & 9.97 & $22 \cdot 8$ & $21 \cdot 0$ & $2 \cdot 52$ & 18.7 & $2 \cdot 05$ & 22.6 & $2 \cdot 71$ \\
\hline $18 \cdot 1$ & $27 \cdot 2$ & 2.06 & $27 \cdot 0$ & 0.61 & $22 \cdot 8$ & 1.77 & $16 \cdot 1$ & 300 & $19 \cdot 4$ & $2 \cdot 19$ & $15 \cdot 5$ & $2 \cdot 47$ \\
\hline $18 \cdot 2$ & $32 \cdot 6$ & $1 \cdot 13$ & $31 \cdot 3$ & $1 \cdot 12$ & $35 \cdot 7$ & 1.62 & $26 \cdot 8$ & 1.64 & $26 \cdot 1$ & 1.61 & $24 \cdot 3$ & $2 \cdot 19$ \\
\hline $20 \cdot 0$ & 0.05 & 0.05 & $0 \cdot 04$ & 0.04 & $0 \cdot 17$ & $0 \cdot 14$ & \multicolumn{2}{|c|}{0.00} & \multicolumn{2}{|c|}{0.00} & \multicolumn{2}{|c|}{0.00} \\
\hline $18 \cdot 3$ & 1.04 & $0 \cdot 11$ & 0.88 & 0.02 & 0.76 & $0 \cdot 17$ & 0.46 & $0 \cdot 16$ & 0.62 & $0 \cdot 08$ & 0.45 & 0.07 \\
\hline $22 \cdot 0$ & $0 \cdot 15$ & $0 \cdot 12$ & $0 \cdot 48$ & 0.21 & 0.03 & 0.03 & 0.75 & 0.11 & 0.68 & $0 \cdot 11$ & 0.63 & $0 \cdot 12$ \\
\hline $20 \cdot 4$ & $5 \cdot 33$ & 1.77 & 5.67 & $1 \cdot 30$ & 8.69 & $2 \cdot 55$ & $12 \cdot 1$ & $2 \cdot 11$ & $10 \cdot 5$ & 1.75 & $10 \cdot 9$ & 1.81 \\
\hline $20 \cdot 5$ & 0.46 & 0.12 & $0 \cdot 26$ & 0.04 & 0.32 & 0.09 & $0 \cdot 19$ & 0.06 & $0 \cdot 15$ & 0.06 & $0 \cdot 24$ & 0.07 \\
\hline $22 \cdot 6$ & 0.56 & $0 \cdot 28$ & $0 \cdot 16$ & 0.09 & $0 \cdot 13$ & 0.05 & $0 \cdot 80$ & 0.35 & 0.41 & 0.27 & 0.63 & 0.32 \\
\hline PUFA & $40 \cdot 0$ & 1.90 & $38 \cdot 3$ & $1 \cdot 49$ & $45 \cdot 6$ & $2 \cdot 23$ & $40 \cdot 4$ & $1 \cdot 03$ & $38 \cdot 4$ & 0.62 & $36 \cdot 5$ & 0.93 \\
\hline
\end{tabular}

PUFA, polyunsaturated fatty acids.

* For details of diets and procedures, see Tables 1 and 2 and pp. 54-57.

Table 5. Fatty acid composition ( $\mathrm{g} / 100 \mathrm{~g}$ total fatty acids) of neutral and polar lipid fractions of lung of chicks fed on diets containing heated sunflower oil (HSO), heated, a-tocopheryl acetate-supplemented sunflower oil (HSE) or fresh sunflower oil (FSO)*

(Mean values with their standard errors for six determinations)

\begin{tabular}{|c|c|c|c|c|c|c|c|c|c|c|c|c|}
\hline \multirow[b]{3}{*}{ Fatty acid } & \multicolumn{6}{|c|}{ Neutral lipids } & \multicolumn{6}{|c|}{ Polar lipids } \\
\hline & \multicolumn{2}{|c|}{$\mathrm{HSO}$} & \multicolumn{2}{|c|}{ HSE } & \multicolumn{2}{|c|}{ FSO } & \multicolumn{2}{|c|}{$\mathrm{HSO}$} & \multicolumn{2}{|c|}{ HSE } & \multicolumn{2}{|c|}{$\mathrm{FSO}$} \\
\hline & Mean & $\mathrm{SE}$ & Mean & SE & Mean & SE & Mean & $\mathrm{SE}$ & Mean & SE & Mean & $\mathrm{SE}$ \\
\hline 160 & $24 \cdot 7^{\mathrm{a}}$ & 0.85 & $22 \cdot 6^{a b}$ & 0.67 & $21 \cdot 2^{\mathrm{b}}$ & $0 \cdot 72$ & $37 \cdot 5$ & 1.66 & $36 \cdot 6$ & $2 \cdot 08$ & $36 \cdot 0$ & 1.64 \\
\hline $16 \cdot 1$ & $1 \cdot 47$ & $0 \cdot 20$ & $2 \cdot 33$ & 0.56 & $1 \cdot 70$ & $0 \cdot 30$ & $1 \cdot 22$ & 0.11 & 1.68 & 0.21 & $1 \cdot 26$ & $0 \cdot 19$ \\
\hline $18 \cdot 0$ & $14 \cdot 2^{a}$ & 0.96 & $10 \cdot 6^{\mathrm{b}}$ & $1 \cdot 23$ & $11 \cdot 8^{a b}$ & $1 \cdot 67$ & $9 \cdot 05$ & $0 \cdot 23$ & $8 \cdot 60$ & 0.23 & $9 \cdot 79$ & 0.63 \\
\hline $18 \cdot 1$ & $24 \cdot 0$ & 1.55 & $24 \cdot 6$ & $2 \cdot 30$ & $25 \cdot 3$ & $2 \cdot 14$ & $12 \cdot 0$ & 0.58 & $14 \cdot 9$ & $1 \cdot 78$ & $13 \cdot 7$ & $1 \cdot 42$ \\
\hline $18 \cdot 2$ & $24 \cdot 4$ & 1.09 & 24.9 & $1 \cdot 73$ & $28 \cdot 3$ & $2 \cdot 04$ & $10 \cdot 1$ & 0.70 & $12 \cdot 9$ & 1.74 & $13 \cdot 0$ & $2 \cdot 37$ \\
\hline $20 \cdot 0$ & 0.90 & 0.18 & $1 \cdot 27$ & 0.39 & 0.92 & 0.41 & \multicolumn{2}{|c|}{$0 \cdot 00$} & \multicolumn{2}{|c|}{0.00} & $0 \cdot 10$ & 0.03 \\
\hline $18 \cdot 3$ & 0.68 & 0.04 & 3.76 & $3 \cdot 10$ & 0.51 & 0.23 & \multicolumn{2}{|c|}{$0 \cdot 00$} & $0 \cdot 16$ & $0 \cdot 16$ & 0.30 & $0 \cdot 10$ \\
\hline $22 \cdot 0$ & 0.47 & $0 \cdot 26$ & $0 \cdot 76$ & $0 \cdot 36$ & 0.53 & $0 \cdot 27$ & \multicolumn{2}{|c|}{$0-00$} & $0 \cdot 32$ & $0 \cdot 12$ & 0.76 & 0.25 \\
\hline $20 \cdot 4$ & 7.89 & $1 \cdot 18$ & $7 \cdot 71$ & $2 \cdot 52$ & $9 \cdot 47$ & $2 \cdot 42$ & $11 \cdot 6$ & 0.53 & $10 \cdot 8$ & 0.74 & $11 \cdot 5$ & 1.04 \\
\hline $20 \cdot 5$ & 0.41 & 0.12 & $0 \cdot 28$ & 0.15 & \multicolumn{2}{|c|}{0.00} & \multicolumn{2}{|c|}{0.00} & \multicolumn{2}{|c|}{0.00} & 0.34 & 0.11 \\
\hline $\mathrm{U}$ & 0.77 & 0.26 & $1 \cdot 24$ & 0.51 & 0.25 & $0 \cdot 17$ & $18 \cdot 6^{\mathrm{a}}$ & 0.94 & $14 \cdot 0^{b}$ & $1 \cdot 18$ & $13 \cdot 3^{b}$ & $2 \cdot 02$ \\
\hline PUFA & $34 \cdot 2^{\mathrm{b}}$ & $1 \cdot 18$ & $37 \cdot 9^{\mathrm{ab}}$ & $2 \cdot 38$ & $38 \cdot 6^{\mathrm{a}}$ & $0 \cdot 70$ & $40 \cdot 2$ & 1.51 & $37 \cdot 9$ & 0.80 & $38 \cdot 4$ & $1 \cdot 22$ \\
\hline
\end{tabular}

a. b For neutral or polar lipids, mean values with unlike superscript letters were significantly different $(P<0 \cdot 05)$.

U, unknown; PUFA, polyunsaturated fatty acids.

* For details of diets and procedures, see Tables 1 and 2 and pp. 54-57. 
heart polar lipids between groups. In lung polar lipids an unknown fatty acid which eluted slightly earlier than 22:6 was significantly increased in chicks fed on HSO compared with the other groups.

\section{DISCUSSION}

In the present study a significant growth depression was observed when chicks were fed on HSO, relative to those fed on FSO or HSE. There are several reports in the literature showing that feeding heat-abused fats or oils depresses animal growth (Calabotta \& Shermer, 1985; Lin et al. 1989). Because of the complex nature of the products formed when fats are oxidized, growth depression could be due to a number of factors, including differences in feed consumption, digestibility and protein quality. Lin et al. (1989) reported a $4.2 \%$ decrease in body weight of broilers fed on oxidized sunflower oil diets containing no added tocopherol, compared with that of birds fed on fresh sunflower oil diets. Feed consumption did not differ significantly between groups. These authors suggested that the decreased body weight could be partly due to a toxic effect of lipid oxidation products, and partly to a decrease in the biological value of the heated oil, destruction of fat-soluble vitamins and carotenoids, and lower protein quality due to reaction of dietary protein with oxidation products. In the present study feed consumption was not measured because the birds generally scattered a considerable amount of the feed and, thus, it is not clear whether the palatability of HSO and HSE was similar to that of FSO. However, the reduced weight gain in chicks fed on HSO was probably a combined effect of oxidation products and $\alpha$ tocopherol deficiency since the feeding of oxidized oil with adequate $\alpha$-tocopherol did not depress growth significantly (HSE $v$. FSO), while in a previous study $\alpha$-tocopherol deficiency did not depress weight gain (Sheehy et al. 1991).

Chicks fed on HSO had extremely low plasma and tissue $\alpha$-tocopherol concentrations. This finding would be expected since the diet contained only $1.3 \mathrm{mg} \alpha$-tocopherol $/ \mathrm{kg}$. Of greater interest, however, was the observation that the $\alpha$-tocopherol concentrations of plasma and tissues (except brain) of the HSE group were significantly lower than those of chicks fed on FSO. The values ranged from 29.6 to $86.1 \%$ of the FSO values. The reduction was more pronounced in tissues rich in $\alpha$-tocopherol, possibly because of the relatively fast turnover of the vitamin in these tissues (Ingold et al. 1987a). The studies of Lin et al (1989) showed that $\alpha$-tocopherol concentrations in dark and white muscle of broilers fed on oxidized sunflower oil were significantly lower than those of birds fed on fresh oil. However, in their study no attempt was made to correct for the tocopherol destroyed by heating, so the $\alpha$-tocopherol content of the oxidized-oil diet was considerably lower than that of the fresh-oil diet. Thus, their results may simply have been due to a lower intake of $\alpha$-tocopherol. Although HSE and FSO in the present study were formulated to contain the same concentration of $\alpha$-tocopherol, the pooled sample of HSE analysed at the end of the experiment had a slightly lower $\alpha$-tocopherol concentration than the pooled FSO $(25 \cdot 1$ (SE 1.1) v. 30.0 (SE 3.9$) \mathrm{mg} / \mathrm{kg}$, or a mean value of $84 \%$ ). The difference was probably due to problems in sampling or deterioration of $\alpha$-tocopherol during storage, rather than because of errors in the formulation of the diet, since the $\alpha$-tocopherol levels in the fresh and heated oils were measured before the diets were prepared. However, even if this difference existed during the entire feeding study it would be unlikely to account for the large depression in $\alpha$-tocopherol concentration observed in some HSE tissues, especially liver, heart and plasma, in which tocopherol levels were only about $30-40 \%$ of the FSO values. The reduced levels could be due to the destruction of $\alpha$-tocopherol in the gastrointestinal tract by free radicals present in the heated oil, including those produced by $\mathrm{Fe}$ - or $\mathrm{Cu}$-catalysed breakdown of hydroperoxides. Alternatively, the hydrolysis of $\alpha$-tocopheryl acetate in the 
intestine may be impaired by lipid oxidation products. In either case the amount of $\alpha$ tocopherol available for absorption would be reduced. A third possibility could be that $\alpha$ tocopherol in plasma is oxidized by peroxyl radicals or lipid hydroperoxides absorbed from the diet. However, the available evidence indicates that lipid hydroperoxides are poorly absorbed, while peroxyl radicals would be expected to react with other unsaturated fatty acids either in the gastrointestinal tract or in the enterocyte, rather than being transferred to the lymph or plasma in that form. Thus, the oxidation of plasma $\alpha$-tocopherol by hydroperoxides or peroxyl radicals from the diet should not be a major factor, although it may be speculated that the absorption and subsequent breakdown of even small quantities of lipid hydroperoxides could be sufficient to initiate free-radical chain reactions in plasma. Furthermore, because of the large number of oxidation products present in thermallyabused oils, other compounds could play a role in degrading plasma $\alpha$-tocopherol. Izaki $e t$ al. (1984) reported that feeding oxidized rapeseed oil at graded levels of deterioration (in diets containing $90 \mathrm{mg} \alpha$-tocopheryl acetate $/ \mathrm{kg}$ ) to rats decreased serum and liver $\alpha$ tocopherol concentrations and increased liver TBARS in proportion to the degree of oxidative damage of the oil. These authors speculated that $\alpha$-tocopherol is degraded by oxidation products in the intestinal lumen or in liver membranes, and suggested that unsaturated keto compounds formed in heated oils, such as 12-keto oleate, may be absorbed and cause lipid peroxidation in vivo. Although the quantities of oxidized lipids consumed by the chicks in the present study are much higher than those likely to be consumed in a normal diet, it is nevertheless of considerable interest that plasma and tissue $\alpha$-tocopherol concentrations were negatively influenced by feeding oxidized dietary lipids, given that $\alpha$-tocopherol is the major lipid-soluble chain-breaking antioxidant in both plasma (Burton et al. 1982; Ingold et al. 1987b; Niki et al. 1988) and other tissues (Cheeseman et al. 1986, 1988), and the current widespread interest in the role of lipid peroxidation and free-radical defence mechanisms in the aetiology and prevention of various chronic disease states.

A significant inverse correlation was observed between the log of plasma $\alpha$-tocopherol concentration and the concentration of TBARS in plasma (Fig. 3). There is some evidence that malondialdehyde absorption occurs in rats (Draper et al. 1984), but evidence is lacking on this point in chicks. It would be expected that if chicks absorb malondialdehyde and other lipid oxidation products, then the concentration of TBARS in plasma of both the HSO and HSE groups should be high, since both diets contained peroxidized lipids. However, this effect was not observed in the present study. Plasma TBARS concentrations for the HSE group, although slightly higher, did not differ significantly from those of the group fed on FSO (Fig. 2). This finding suggests that the significant elevation in TBARS concentrations in the plasma of chicks fed on HSO resulted from peroxidation of plasma lipids, rather than from absorption of malondialdehyde and other TBA-reactive substances from the gastrointestinal tract, and were due to the lower concentrations of $\alpha$-tocopherol in plasma. The observed relationship between plasma $\alpha$-tocopherol and TBARS is in agreement with previous results from this laboratory in chicks fed on various levels of $\alpha$ tocopherol. A similar relationship between plasma $\alpha$-tocopherol and plasma malondialdehyde concentrations has been observed in trout (Frigg et al. 1990).

Our finding that plasma and tissue $\alpha$-tocopherol concentrations were significantly correlated (Table 3) extends our previous observation that plasma $\alpha$-tocopherol concentration is a good indicator of tissue $\alpha$-tocopherol status in the young chick (Sheehy et al. 1991) and supports that of Whitacre et al. (1987) who observed a significant direct correlation between plasma $\alpha$-tocopherol concentration and the concentration of $\alpha$ tocopherol in liver, heart and pancreas of chicks fed on various concentrations of the vitamin. 
The increased susceptibility of tissues (except brain) of chicks fed on HSO and HSE to Fe-ascorbate-induced lipid oxidation (Fig. 4) was probably due to the lower levels of $\alpha$ tocopherol in these tissues, since susceptibility to lipid oxidation is markedly influenced by tissue $\alpha$-tocopherol concentration (Franco \& Jenkinson, 1986; Hu et al. 1989; Leibovitz et al. 1990). Because of the important role played by $\alpha$-tocopherol in preventing oxidative deterioration of chicken muscle during refrigerated and frozen storage (Marusich et al. 1975), the feeding of diets containing thermally-abused oils to chicks may reduce the storage stability of chicken meat and meat products, particularly those containing precooked or comminuted meat.

The effect of feeding diets containing heated or fresh sunflower oil on the fatty acid composition of chick tissues was also investigated in the present study (Tables 4 and 5). In general, the differences observed between groups were rather small, particularly when the slight differences in fatty acid composition of the diets are taken into account (Table 2). Because of the dependence of tissue fatty acid composition on the composition of dietary lipids, it is likely that tissue fatty acid compositions of chicks fed on HSO and HSE would differ more substantially from those of chicks fed on FSO if the heating procedure had destroyed a greater proportion of linoleic acid in the sunflower oil.

In conclusion, the feeding of HSO to chicks significantly reduced body weight gain compared with feeding FSO or HSE. The presence of oxidation products in diets was associated with a significant reduction in $\alpha$-tocopherol concentrations in plasma and other tissues. Plasma $\alpha$-tocopherol concentrations were positively correlated with those in other tissues, while plasma TBARS were negatively correlated with log plasma $\alpha$-tocopherol. Generally, susceptibility of tissues to Fe-ascorbate-induced lipid oxidation was increased by feeding HSO.

Supplementing HSO with $\alpha$-tocopheryl acetate (HSE) reduced susceptibility to varying degrees, depending on the tissue. Minor changes in the fatty acid composition of liver, heart and lung were observed. The results suggest that chronic ingestion of thermally-oxidized lipids may compromise the activity of free-radical defence mechanisms in vivo by depleting $\alpha$-tocopherol in the gastrointestinal tract, or possibly in plasma and other tissues.

\section{REFERENCES}

Addis, P. B. \& Warner, G. J. (1991). The potential health aspects of lipid oxidation products in food. In Free Radicals and Food Additives, pp. 77-119 [O. I. Arouma and B. Halliwell, editors]. London: Taylor \& Francis. Artman, N. R. (1969). The chemical and biological properties of heated and oxidized fats. In Advances in Lipid Research, vol. 7, pp. 245-330 [R. Paoletti and D. Kritchevsky, editors]. London: Academic Press.

Beuge, J. A. \& Aust, S. D. (1978). Microsomal lipid peroxidation. Methods in Enzymology 52, 302-311.

Brubacher, G., Muller-Mulot, W. \& Southgate, D. A. T. (editors) (1985). Vitamin E (only $\alpha$-tocopherol) in foodstuffs: HPLC method. In Methods for the Determination of Vitamins in Food, pp. 97-106. Barking: Elsevier Applied Science,

Budowski, P., Bartov, I., Dror, Y. \& Frankel, E. N. (1979). Lipid oxidation products and chick nutritional encephalopathy. Lipids 14, 768-772.

Budowski, P., Hawkey, C. M. \& Crawford, M. A. (1980). L'effet protecteur de l'acide $\alpha$-linolénique sur l'encéphalomalacie chez le poulet (The protective effect of $\alpha$-linolenic acid on encephalopathy in the chick). Annales de Nutrition et de l'Alimentation 34, 389-400.

Burton, G. W., Foster, D. O., Perly, B., Slater, T. F., Smith, I. C. P. \& Ingold, K. U. (1985a). Biological antioxidants. Philosophical Transactions of the Royal Society B 311, 565-578.

Burton, G. W., Joyce, A. \& Ingold, K. U. (1982). First proof that vitamin E is the major lipid-soluble, chainbreaking antioxidant in human blood plasma. Lancet ii, 327-328.

Burton, G. W., Joyce, A. \& Ingold, K. U. (1983). Is vitamin E the only chain-breaking antioxidant in human blood plasma and erythrocyte membranes? Archives of Biochemistry and Biophysics 221, 281-290.

Burton, G. W., Webb, A. \& Ingold, K. U. (1985b). A mild, rapid and efficient method of lipid extraction for use in determining vitamin E/lipid ratios. Lipids 20, 29-39.

Buttriss, J. L. \& Diplock, A. T. (1984). High performance liquid chromatographic methods for vitamin E in tissues. Methods in Enzymology 105, 131-138.

Calabotta, D. F. \& Shermer, W. D. (1985). Controlling feed oxidation can be rewarding. Feedstuffs 57, 24-33.

Cheeseman, K. H., Collins, M., Proudfoot, K., Slater, T. F., Burton, G. W., Webb, A. C. \& Ingold, K. U. (1986). 
Studies on lipid peroxidation in normal and tumour cells : the Novikoff rat liver tumour. Biochemical Journal 235, 507-514.

Cheeseman, K. H., Emery, S., Maddix, S. P., Slater, T. F., Burton, G. W. \& Ingold, K. U. (1988). Studies on lipid peroxidation in normal and tumour tissues: the Yoshida rat liver tumour. Biochemical Journal 250, 247252.

Draper, H. H., Polensek, L., Hadley, M. \& McGirr, L. G. (1984). Urinary malondialdehyde as an indicator of lipid peroxidation in the diet and in the tissues. Lipids 19,836-843.

Franco, D. P.\& Jenkinson, S. G. (1986). Rat lung microsomal lipid peroxidation: effects of vitamin E and reduced glutathione. Journal of Applied Physiology 61, 785-790.

Frei, B., Stocker, R. \& Ames, B. M. (1988). Antioxidant defences and lipid peroxidation in human blood plasma. Proceedings of the National Academy of Sciences, U.S.A. 85, 9748-9752.

Frigg, M., Prabucki, A. L. \& Ruhdel, E. U. (1990). Effect of dietary vitamin E levels on oxidative stability of trout fillets. Aquaculture 84, $145-158$.

Glavind, J., Christensen, F. \& Sylven, C. (1971). Intestinal absorption and in vivo formation of lipoperoxides in vitamin E-deficient rats. Acta Chemica Scandinavica 25, 3220-3226.

Hu, M. L., Frankel, E. D., Leibovitz, B. E. \& Tappel, A. L. (1989). Effect of dietary lipids and vitamin E on in vitro lipid peroxidation in rat liver and kidney homogenates. Journal of Nutrition 119, 1574-1582.

Ingold, K. U., Burton, G. W., Foster, D. O., Hughes, L., Lindsay, D. A. \& Webb, A. (1987a). Biokinetics of and discrimination between dietary RRR- and SSR- $\alpha$-tocopherols in the male rat. Lipids 22, 163-172.

Ingold, K. U., Webb, A. C., Witter, D., Burton, G. W., Metcalfe, T. A. \& Muller, D. P. R. (1987b). Vitamin E remains the major lipid-soluble, chain-breaking antioxidant in human plasma even in individuals suffering severe vitamin E deficiency. Archives of Biochemistry and Biophysics 259, 224-225.

Izaki, Y., Yoshikawa, S. \& Uchiyama, M. (1984). Effect of ingestion of thermally oxidized frying oil on peroxidative criteria in rats. Lipids $19,324-331$.

Kanazawa, K., Kanazawa, E. \& Natake, M. (1985). Uptake of secondary autoxidation products of linoleic acid by the rat. Lipids $20,412-419$.

Kornbrust, D. J. \& Mavis, R. D. (1980). Relative susceptibility of microsomes from lung, heart, liver, kidney, brain and testes to lipid peroxidation: correlation with vitamin E content. Lipids 15, 315-322.

Lea, C. H. (1946). The determination of the peroxide values of edible fats and oils: the iodometric method. Journal of the Society of Chemical Industry 65, 286-290.

Leibovitz, B. E., Hu, M. L. \& Tappel, A. L. (1990). Lipid peroxidation in rat tissue slices : effects of dietary vitamin E, corn oil-lard and menhaden oil. Lipids 25, 286-290.

Lin, C. F., Asghar, A., Gray, J. I., Buckley, D. J., Booren, A. M., Crackel, R. L. \& Flegal, C. J. (1989). Effects of oxidized dietary oil and antioxidant supplementation on broiler growth and meat stability. British Poultry Science 30, 855-864.

Lowry, O. H., Rosebrough, N. J., Farr, A. L. \& Randall, R. J. (1951). Protein measurement with the Folin phenol reagent. Journal of Biological Chemistry 193, 265-275.

Marmer, W. N. \& Maxwell, R. J. (1981). Dry column method for the quantitative extraction and simultaneous class separation of lipids from muscle tissue. Lipids 16, 365-371.

Marusich, W. L. (1980). Vitamin $\mathrm{E}$ as an in vivo lipid stabilizer and its effect on flavour and storage properties of milk and meat. In Vitamin E: A Comprehensive Treatise, pp. 445-472 [L. J. Machlin, editor]. New York: Marcel Dekker.

Marusich, W. L., DeRitter, E., Ogring, E. F., Keating, J., Mitrovic, M. \& Bunnell, R. H. (1975). Effect of supplemental vitamin E in control of rancidity in poultry meat. Poultry Science 54, 831-844.

Maxwell, R. J. \& Marmer, W. N. (1983). Systematic protocol for the accumulation of fatty acid data from multiple tissue samples: tissue handling, lipid extraction and class separation, and capillary gas chromatographic analysis. Lipids $\mathbf{1 8}, 453-459$.

Naruszewicz, M., Wozny, E., Mirkiewicz, E., Nowicka, G. \& Szostak, W. B. (1987). The effect of thermally oxidized soyabean oil on metabolism of chylomicrons: increased uptake and degradation of oxidized chylomicrons in cultured mouse macrophages. Atherosclerosis 66, 45-53.

Niki, E., Yamamoto, Y., Takahashi, M., Yamamoto, K., Yamamoto, Y., Komuro, E., Miki, M., Yasduda, H. \& Mino, M. (1988). Free radical-mediated damage of blood and its inhibition by antioxidants. Journal of Nutritional Science and Vitaminology 34, 507-512.

Ryan, T. A., Joiner, B. L. \& Ryan, B. F. (1986). Comparing two means: confidence intervals and tests. In Minitab Student Handbook, pp. 181-192 [T. A. Ryan, B. L. Joiner and B. F. Ryan, editors]. Boston: Duxbury Press.

Shearer, M. J. (1986). Vitamins. In HPLC of Small Molecules, pp. 173-180 [C. K. Lim, editor]. Oxford: IRL Press.

Sheehy, P. J. A., Morrissey, P. A. \& Flynn, A. (1991). Influence of dietary $\alpha$-tocopherol on tocopherol concentrations in chick tissues. British Poultry Science 32, 391-397.

Slover, H. T. \& Lanza, E. (1979). Quantitative analysis of food fatty acids by capillary gas chromatography. Journal of the American Oil Chemists Society 56, 933-943.

Whitacre, M. E., Combs, G. F. Jr., Combs, S. B. \& Packer, R. S. (1987). Influence of vitamin E on nutritional pancreatic atrophy in selenium-deficient chicks. Journal of Nutrition 117, 460-467.

Wiseman, J. (1986). Antinutritional factors associated with dietary fats and oils. In Recent Advances in Animal Nutrition, pp. 47-75 [W. Haresign and D. J. A. Cole, editors]. London: Butterworths.

Yagi, K. (1984). Assay for blood plasma or serum. Methods in Enzymology 105, 328-331. 